\title{
Preparing for ABET 2000: Assessment at the Classroom Level
}

\author{
Patrick T. Terenzini \\ Alberto F. Cabrera \\ John M. Parente \\ Stefani A. Bjorklund \\ The Pennsylvania State University
}

The nature of the classroom experience has recently regained recognition as one of the most significant factors influencing college students' cognitive and affective development. While knowledge of the role of classroom experiences is extensive in general education (Pascarella $\&$ Terenzini, 1991), the influences of these experiences among engineering students is as yet little understood. The absence of such information presents colleges and schools of engineering with major problems. Industry and the Accreditation Board for Engineering and Technology (ABET) are bringing increasing pressure on engineering schools to produce graduates who are prepared to engage in unstructured problem solving and to work in groups. ABET is also moving to an assessment-based reaccreditation review process, requiring institutions to produce evidence that their programs "prepare graduates for the practice of engineering at a professional level" (Accreditation Board for Engineering and Technology, 1997, p. 41).

This paper reports the results of a project that developed and validated a measure of classroom activities and student learning outcomes among undergraduate students enrolled in engineering courses. The measure was pilot tested at six of the seven colleges of engineering that make up the Engineering Coalition of Schools for Excellence in Education and Leadership (ECSEL). With support from the National Science Foundation, ECSEL has sought (among its several goals) to enhance undergraduate engineering students' learning through the introduction and diffusion of design throughout the undergraduate engineering curriculum on their campuses. The fundamental question examined in this study was whether design activities (including working in teams; unstructured, practical, problem-solving activities; the hands-on application of scientific and engineering theory and principles to realworld problems, and extensive, active student involvement in the teaching-learning process) are any more effective in developing students' engineering skills than are more traditional and widespread instructional practices, such as lectures and discussions.

\section{Methods}

To address that question, the ECSEL evaluation group at the Center for the Study of Higher Education (CSHE) at the Pennsylvania State University developed the "Classroom Activities and Outcomes Survey." This pencil-and-paper, multiple-choice questionnaire was pilot-tested at the end of the Spring, 1997 semester. Because this data collection was a pilot test for a larger, more systematic assessment planned for Spring, 1998, participating courses and students were not randomly selected. Each campus's local evaluator was asked to identify at 
least one ECSEL and (for comparative purposes) one non-ECSEL course. The four-page questionnaire (see attachment) was then distributed and completed during a class session. The survey form gathers information in three categories:

1) students' personal and academic background and demographic characteristics; 2) the characteristics of the course in which they were enrolled when completing the questionnaire, and 3) the extent to which they believed they made progress in a variety of learning and skill development areas as a result of taking that particular course. Completed questionnaires were returned to CSHE for data entry and analysis.

The items comprising each of the three sections of the questionnaire were derived from learning theory, research on college students, and from Delphi studies by Jones (1994a, 1994b). Jones sought to clarify and develop consensus among faculty members, administrators, researchers, and employers on definitions and components of "critical thinking," "problem solving," and "communication" skills. Items were selected from this study, or developed specifically, to reflect as closely as possible the learning outcomes criteria articulated in ABET's Engineering Criteria 200 (Accreditation Board for Engineering and Technology, 1997).

\section{Results}

\section{Student Characteristics}

A total of 480 students on the six campuses completed usable assessment forms. Overall, a total of 17 ECSEL courses/sections and 6 non-ECSEL courses/sections were surveyed. Of the 480 students who completed usable forms, 339 (71\%) were enrolled in an ECSEL course while $141(29 \%)$ were in non-ECSEL courses. Of the total of 480 students (and because of the non-random nature of the data collection), 48 percent were enrolled at the University of Washington, 22 percent at the University of Maryland, 19 percent at City College of New York (CCNY), and 11 percent were enrolled at Howard University, Morgan State University, or Pennsylvania State University. Of the 339 ECSEL students, 53 percent came from the University of Washington, 20 percent from Maryland, and 15 percent from CCNY; 12 percent came from a combination of Howard, Morgan State, and Penn State courses and students.

Overall, 24 percent of the respondents had declared (or intended to declare) mechanical engineering as their major. About 10 percent each of the usable responses came from civil or architectural engineering and from computer or electrical engineering. One-third did not report a declared/intended major within engineering.

Seventy-seven percent of the respondents were males, and 45 percent were white Americans. Twenty-three percent were Asian American or Pacific Islanders, while 15 percent were African Americans, and 5 percent reported themselves to be Hispanic (10\% reported another race/ethnicity or did not respond to the question). Students from historically under represented groups were slightly over-represented among the "ECSEL-course" students. 
Students were approximately evenly distributed across the class years, with 25-27 percent in each of the freshman, sophomore, and junior classes, although slightly fewer (18\%) were seniors. No significant differences in this distribution were identified between ECSEL and non-ECSEL course students.

Non-ECSEL students reported somewhat stronger pre-college academic credentials than did the ECSEL-course students. Compared to their ECSEL-peers, non-ECSEL students reported higher SAT scores (by 30 and 35 points on the verbal and math portions of the SATs, respectively) and high school grade-point averages. Each of these differences were statistically significant. No statistically significant differences were identified, however, between the two groups with respect to current engineering GPA or overall GPA.

\section{Course Characteristics}

Students were asked to indicate how often they (or the instructor) engaged in each of 24 instruction-related activities. The scale ranged from 1 to 4 , where $1=$ "never," $2=$ "occasionally," 3 = "often," and 4 = "very often/almost always." (Students were also given a "not applicable" option; "N/A" responses were excluded in the calculation of group means and statistical tests.) The items were drawn from the research literature identifying effective instructional approaches and activities.

Table 1 reports the group means on the 18 of 24 items on which the groups differed at statistically significant levels $(\mathrm{p}<.05$; i.e., the probability that a difference of that size is due to chance rather than being "real" is less than 5 percent; in most cases, the probability was less than one-tenth of one percent). For interpretative ease, the items have been grouped in four clusters: collaborative (or group) learning activities, problem solving activities, feedback from instructors and peers, and interactions with faculty members and other students. As can be seen in Table 1, the ECSEL-course students' mean was higher than that of their non-ECSEL peers on 17 of the 18 items. Only on the item dealing with the extent to which students in the course were treated similarly regardless of their gender did the non-ECSEL students rate their course higher than the ECSEL-course students. A similar, but statistically non-significant ( $\mathrm{p}<$ .07) relation is suggested in the item dealing with the equality of treatment regardless of students' race/ethnicity. While the relation is not a strong one, it is nonetheless inconsistent with ECSEL's goals to improve persistence among women and historically under represented students. One possible explanation is that this finding is a function of the instructional approaches used in the two different settings. In conventional (usually lecture and discussion) courses, instructors engage students in an "I pitch, you catch" relationship that affords few opportunities for students to interact with the instructor or their peers. ECSEL courses, on the other hand, with their emphasis on group work and collaborative learning, provide more 
Table 1. Course Characteristics with Statistically-significant Group Differences

\begin{tabular}{|c|c|c|c|}
\hline \multirow[b]{2}{*}{ Course Characteristics } & \multicolumn{2}{|c|}{ Means $^{\mathrm{a}}$} & \multirow[b]{2}{*}{$\begin{array}{l}\text { Effect } \\
\text { Size }^{b}\end{array}$} \\
\hline & $\begin{array}{c}\text { ECSEL } \\
(\mathbf{n}=\mathbf{2 9 1 - 3 3 1 )}\end{array}$ & $\begin{array}{l}\text { Non-ECSEL } \\
(n=122-139)\end{array}$ & \\
\hline \multicolumn{4}{|l|}{ Collaborative Learning } \\
\hline $\begin{array}{l}\text { I work cooperatively with other students on course } \\
\text { assignments. }\end{array}$ & 3.21 & 2.50 & +25 \\
\hline Students teach and learn from each other. & 2.96 & 2.60 & +14 \\
\hline There are opportunities to work in groups. & 3.51 & 2.20 & +39 \\
\hline $\begin{array}{l}\text { I discuss ideas with my classmates (either as } \\
\text { individuals or in a group). }\end{array}$ & 3.14 & 2.51 & +23 \\
\hline $\begin{array}{l}\text { We do things requiring students to be active } \\
\text { participants in the teaching/learning process. }\end{array}$ & 2.92 & 1.91 & +35 \\
\hline $\begin{array}{l}\text { Instructor guides students' learning activities rather } \\
\text { than lecturing or demonstrating course material. }\end{array}$ & 2.74 & 1.99 & +28 \\
\hline $\begin{array}{l}\text { Instructor encourages students to listen, to evaluate, } \\
\text { and to learn from the ideas of others. }\end{array}$ & 2.98 & 2.11 & +31 \\
\hline Instructor emphasizes design process and activities. & 3.04 & 2.39 & +26 \\
\hline \multicolumn{4}{|l|}{ Problem Solving Activities } \\
\hline $\begin{array}{l}\text { I'm encouraged to show how a particular course } \\
\text { concept can be applied to an actual problem or } \\
\text { situation. }\end{array}$ & 3.04 & $2.79 *$ & +10 \\
\hline $\begin{array}{l}\text { I have opportunities to practice the skills I'm } \\
\text { learning in the course. }\end{array}$ & 2.82 & 2.40 & +16 \\
\hline \multicolumn{4}{|l|}{ Feedback } \\
\hline I get feedback on work/ideas from classmates. & 2.83 & 2.20 & +23 \\
\hline Instructor gives frequent feedback on my work. & 2.70 & 2.25 & +18 \\
\hline Instructor gives detailed feedback on my work. & 2.51 & 2.13 & +15 \\
\hline \multicolumn{4}{|l|}{ Interaction with Faculty/Peers } \\
\hline $\begin{array}{l}\text { I'm encouraged to challenge the instructor's or } \\
\text { other student's ideas. }\end{array}$ & 2.68 & 2.34 & +14 \\
\hline I interact with instructor as part of this course. & 2.71 & 2.01 & +26 \\
\hline I interact with this instructor outside of class. & 1.84 & 1.51 & +15 \\
\hline $\begin{array}{l}\text { I interact with other students in this course outside } \\
\text { of class. }\end{array}$ & 2.96 & $2.70^{*}$ & +10 \\
\hline $\begin{array}{l}\text { Students are treated the same, whether male or } \\
\text { female. }\end{array}$ & 3.63 & $3.75^{*}$ & -8 \\
\hline
\end{tabular}

${ }^{\mathrm{a}}$ All means differ at $\mathrm{p}<.001$ with three exceptions (asterisked). The first two differ at $\mathrm{p}<.01$, the third at $\mathrm{p}<.05$.

${ }^{b}$ Difference in means represented in percentile-point units. Effect size represents the advantage $(+)$ or disadvantage (-) to ECSEL courses compared with non-ECSEL courses, with the non-ECSEL reference group mean set at the 50th percentile. 
occasions for students to interact with one another, more opportunities to encounter (and engage?) other students with different ideas, personalities, and value sets. Such encounters with people and ideas different from one's own, of course, may be the first step in a developmental growth process.

The other 17 items on which the two groups differ, however, constitute strong evidence not only that what happens in ECSEL-courses is systematically and significantly (statistically) different from the activities reported by students in non-ECSEL courses, but also that those activities are ones other research has shown to be related to greater learning gains among students (see, for example, Pascarella \& Terenzini, 1991). Compared to their non-ECSEL course peers, and consistent with ECSEL's goals of changing the way undergraduate instruction is delivered, ECSEL-course students consistently report more opportunities to work in groups, greater emphasis on the design process and activities, more active involvement in their own learning, more course-related (and out-of-class) interactions with other students in the course, more in- and out-of-class interaction with faculty members, both more frequent and more detailed feedback on their performance from instructors and peers, and more encouragement from faculty members to challenge the ideas of instructors and other students. A review of the magnitudes of the means for the two groups indicates that (with some few exceptions) the frequencies with which these activities are reported to occur are in the "Occasionally"-range among non-ECSEL students (i.e., means of 2.5 or lower on 13 of the 18 items). ECSEL-course students, however, were more likely to report these instructional activities as occurring in the "Often" range (i.e., group means of 2.75 or above on 11 of the 18 means).

The "Effect Size" column of Table 1 offers additional information on the magnitude of the differences between ECSEL and non-ECSEL course groups in the frequency with which they report a particular classroom activity or condition occurs. The effect size is interpretable as the difference in percentile points between the mean of the ECSEL group and the mean of the non-ECSEL group. Values close to zero indicate no difference in the frequency with which a classroom activity or condition is reported, while effect sizes greater than zero indicate the number of percentile points the ECSEL group students are above the non-ECSEL group of students. For example, if the non-ECSEL group mean on the first item (the frequency with which students report "work[ing] cooperatively with other students on course assignments") constitutes the 50th percentile (the average for that group), the average frequency with which ECSEL group students report that same activity would be 25 percentile points higher, or at the 75 th percentile. On 9 of the 18 items, the ECSEL group mean is 20 or more percentile points higher than that of the non-ECSEL group.

Table 2 lists the survey items on which the two groups did not differ at statistically significant levels (i.e., the differences reported could be chance variations). The groups were not different in the frequency with which they reported instructors were clear in their explanations of course assignments and activities, the relations between course assignments and activities were clear, course workload, the clarity with which instructors let students know what is 
expected of them with respect to level of effort and quality of work, or in the degree of interaction among students and engineering faculty members in general.

Table 2. Course Characteristics with Statistically non-significant Group Differences

\begin{tabular}{lcc}
\hline & \multicolumn{2}{c}{ Means } \\
\cline { 2 - 3 } Course Characteristics & $\begin{array}{c}\text { ECSEL } \\
(\mathbf{n = 2 9 1 - 3 3 1})\end{array}$ & $\begin{array}{c}\text { Non-ECSEL } \\
(\mathbf{n = 1 2 2 - 1 3 9 )}\end{array}$ \\
\hline $\begin{array}{c}\text { Assignments and class activities are clearly } \\
\quad \text { explained. }\end{array}$ & 3.17 & 3.22 \\
$\begin{array}{c}\text { Assignments, presentations, and learning activities } \\
\text { are clearly related to one another. }\end{array}$ & 3.22 & 3.16 \\
$\begin{array}{l}\text { The workload is heavier than in other engineering } \\
\quad \text { courses. }\end{array}$ & 2.43 & 2.60 \\
$\begin{array}{l}\text { Students are treated the same, whether white or a } \\
\text { minority group member. }\end{array}$ & 3.66 & 3.77 \\
$\begin{array}{l}\text { The instructor makes clear what is expected of } \\
\quad \text { students in the way of activities and effort. }\end{array}$ & 3.15 & 3.10 \\
$\begin{array}{c}\text { Excluding this course, I interact with engineering } \\
\text { faculty outside class. }\end{array}$ & 2.08 & 1.93 \\
\hline
\end{tabular}

In sum, the evidence quite clearly and consistently indicates that students in the ECSEL courses studied in this pilot test are exposed more frequently than students in non-ECSEL courses to a range of instructional activities that are consistent with the ECSEL Coalition's goals for enhancing undergraduate instruction. In addition, these instructional activities have been shown in previous research to be more educationally effective. While these findings imply more effective instruction is being delivered in the ECSEL, the evidence is only indirect. The next section shines a more direct light on the extent to which ECSEL courses are more educationally effective than more traditional ones.

\section{$\underline{\text { Learning Outcomes }}$}

The assessment instrument also asked students to indicate the progress they believed they had made in each of 27 areas as a consequence of the course they were taking and for which the survey form was completed. Progress was reported on a 1-to-4 scale, where $1=$ "none," $2=$ "slight," 3 = "moderate," and 4 = "a great deal." The items were drawn primarily (but not exclusively) from a series of Delphi studies by Jones (1994a,b) intended to develop consensus among faculty members, research specialists, academic administrators, and employers on definitions and components of "critical thinking," "problem solving," and "communications." As noted earlier, items were selected from this study, or developed specifically, to reflect as closely as possible the learning outcomes criteria articulated in ABET's Engineering Criteria 200 (Engineering Accreditation Commission, 1997).

Because of the difficulty of making sense and meaning from group scores on so many items (many of which are correlated), a principal components factor analysis of the 27 items (using 
an orthogonal rotation) was carried out to facilitate interpretation of the results from this portion of the study. Factor analysis is a statistical procedure for identifying items which appear to be measuring a common, underlying construct or "factor." Items common to a factor can then be combined into a "scale" and used in subsequent analyses. Scales have the dual advantages of being fewer in number (and, therefore, easier to understand) and more reliable in their representation of the underlying construct or factor.

Table 3 reports the ECSEL and non-ECSEL group means for each of the four scales (in bold face) derived from the factor analysis. The means for the items comprising each scale are reported under the scale heading. Each scale's internal consistency (alpha) reliability is also reported. That index reflects the extent to which the items comprising a scale are measuring the same thing (i.e., are consistent). An alpha coefficient can range from .00 (indicating no consistency whatever and the presence of a great deal of measurement error or "noise") to 1.0 (reflecting perfect consistency: respondents answering one item in a certain way consistently answer similar items in the same way). A scale with an alpha of .70 or above is generally considered psychometrically sound.

As can be seen in Table 3, the factor analysis produced four factors, labeled to reflect their general content (or the underlying "factor"): "Design Skills," "Problem Solving Skills," "Communications Skills," and "Group Skills." The four factors together accounted for 66 percent of the total variance in the items (an unusually high percentage, indicating that relatively little information is lost in using the factors rather than the individual items for subsequent analyses). The factors were also uncommonly clean (i.e., very few items contributed meaningfully [loaded $>.40$ ] on multiple factors, which would indicate an interpretively unclear item). The internal consistency reliabilities of the four scales range from .87 to .93 and are well above the conventional standard for measurement adequacy.

Examination of the group means on each of the scales (and component items) indicates that ECSEL students reported significantly greater gains than non-ECSEL course students in developing their design, communications, and group skills. More impressive is the fact that these differences are not only statistically significant (i.e., the probability is high that the differences are not due to chance), but they are also substantively large. The "Effect Size" figures indicate (again, in percentile point units) the magnitude of the differences in reported gains. As can be seen in Table 3, ECSEL students (compared to their non-ECSEL peers) reported gains that ranged from 11 percentile points higher in developing their communications skills, to a 23 percentile-point advantage in building their design skills, to a 34 percentile-point advantage in developing their group skills.

Only on the Problem Solving Skills scale did the two group not differ at a statistically significant level. The reason for this finding may be attributable, at least in part, to the items that make it up. For example, no statistically significant differences between the groups were detected on 3 of the 5 component items (although the ECSEL group mean was higher than that of the non-ECSEL group on 2 of the 3 items). In addition, on the "the ability to divide problems into manageable components" item, the non-ECSEL group reported significantly greater gains than did the ECSEL group. It may be that this item (and others in this scale as well) did not differentiate sufficiently in respondents' minds between the practical and open- 
ended problems students confronted in ECSEL courses and the structured textbook, mathematical, or computational problems common to most engineering courses. Put another way, "problem" may have had different meanings for the two groups.

Table 3. Course-related Differences in Learning Outcomes

\begin{tabular}{|c|c|c|c|}
\hline \multirow[b]{2}{*}{ Course-related gains in: } & \multicolumn{2}{|c|}{ Means $^{\mathrm{a}}$} & \multirow[b]{2}{*}{$\begin{array}{l}\text { Effect } \\
\text { Size }^{\text {b }}\end{array}$} \\
\hline & $\begin{array}{c}\text { ECSEL } \\
(\mathbf{n}=294-321)\end{array}$ & $\begin{array}{c}\text { Non-ECSEL } \\
(\mathrm{n}=129-138)\end{array}$ & \\
\hline Design Skills (Alpha=.87) & 2.84 & 2.38 & +23 \\
\hline $\begin{array}{l}\text { Understanding of what engineers "do" in industry or } \\
\text { as faculty. }\end{array}$ & 2.91 & 2.62 & +12 \\
\hline $\begin{array}{l}\text { Understanding of engineering as a field that often } \\
\text { involves non-technical considerations (e.g., } \\
\text { economic, political, ethical, and/or social } \\
\text { issues). }\end{array}$ & 2.58 & 1.88 & +27 \\
\hline $\begin{array}{l}\text { Knowledge and understanding of the language of } \\
\text { design in engineering. }\end{array}$ & 2.81 & 2.66 & \\
\hline $\begin{array}{l}\text { Knowledge and understanding of the process of } \\
\text { design in engineering. }\end{array}$ & 3.04 & 2.55 & +19 \\
\hline Your ability to "do" design. & 2.85 & 2.23 & +23 \\
\hline Problem Solving Skills (Alpha=.86) & 2.89 & 2.83 & \\
\hline $\begin{array}{l}\text { Your ability to identify what information is needed } \\
\text { to solve a problem. }\end{array}$ & 3.05 & 3.05 & \\
\hline $\begin{array}{l}\text { Your ability to apply an abstract concept or idea to a } \\
\text { real problem or situation. }\end{array}$ & 2.90 & 2.58 & +14 \\
\hline $\begin{array}{l}\text { Your ability to divide problems into manageable } \\
\text { components. }\end{array}$ & 2.88 & 3.15 & -14 \\
\hline $\begin{array}{l}\text { Your ability to develop several methods which } \\
\text { might be used to solve a problem. }\end{array}$ & 2.84 & 2.77 & \\
\hline $\begin{array}{l}\text { Your ability to use established criteria to evaluate } \\
\text { and prioritize solutions. }\end{array}$ & 2.78 & 2.63 & \\
\hline Communication Skills (Alpha=.86) & 2.84 & 2.57 & $+11 *$ \\
\hline Your ability to clearly describe a problem orally. & 2.85 & 2.51 & +13 \\
\hline $\begin{array}{l}\text { Your ability to clearly describe a problem in } \\
\text { writing. }\end{array}$ & 2.83 & 2.64 & \\
\hline
\end{tabular}


Group Skills (Alpha=.93)

Develop ways to resolve conflict and reach agreement in a group.

Be aware of feelings of other members of the group.

Listen to the ideas of others with an open mind.

Work on collaborative projects as a team member.

Organize information into categories, distinctions, or frameworks that will aid comprehension.

Ask probing questions that clarify facts, concepts, or relationships.

After evaluating the alternatives generated, to develop a new alternative that combines the best qualities and avoids the disadvantages of the previous alternatives.

Table 3 (continued)

\begin{tabular}{|c|c|c|c|}
\hline \multirow[b]{2}{*}{ Course-related gains in: } & \multicolumn{2}{|c|}{ Means $^{a}$} & \multirow[b]{2}{*}{$\begin{array}{l}\text { Effect } \\
\text { Size }^{b}\end{array}$} \\
\hline & $\underset{(n=294-321)}{\text { ECSEL }}$ & $\begin{array}{l}\text { Non-ECSEL } \\
(\mathrm{n}=129-138)\end{array}$ & \\
\hline \multicolumn{4}{|l|}{ Other, Unscaled ${ }^{\mathrm{c}}$ Items $^{2}$} \\
\hline $\begin{array}{l}\text { Your ability to evaluate arguments and evidence so } \\
\text { that the strengths and weaknesses of competing } \\
\text { alternatives can be judged. }\end{array}$ & 2.87 & 2.35 & +21 \\
\hline Your ability to explain your ideas to others. & 3.02 & 2.53 & +18 \\
\hline $\begin{array}{l}\text { Your ability to be patient and tolerate the ideas or } \\
\text { solutions proposed by others. }\end{array}$ & 3.04 & 2.51 & +19 \\
\hline $\begin{array}{l}\text { Your ability to understand that a problem may have } \\
\text { multiple solutions. }\end{array}$ & 3.11 & 2.86 & $+11^{*}$ \\
\hline $\begin{array}{l}\text { Your ability to use discussion strategies to analyze } \\
\text { and solve a problem. }\end{array}$ & 3.03 & 2.55 & +18 \\
\hline $\begin{array}{l}\text { Your ability to recognize contradictions or } \\
\text { inconsistencies in ideas, data, images, etc. }\end{array}$ & 2.89 & 2.32 & +22 \\
\hline $\begin{array}{l}\text { Your ability to identify the constraints on the } \\
\text { practical application of an idea. }\end{array}$ & 2.93 & 2.29 & +24 \\
\hline $\begin{array}{l}\text { Your ability to recognize flaws in your own } \\
\text { thinking. }\end{array}$ & 2.94 & 2.64 & +12 \\
\hline
\end{tabular}

${ }^{a}$ Difference in means are statistically significant at $\mathrm{p}<.001$ UNLESS: a) no effect size is reported, or b) the effect size has an asterisk, in which case the difference in the means is statistically significant at $\mathrm{p}<.01$.

${ }^{\mathrm{b}}$ Difference in means represented in percentile-point units. Effect size represents the advantage $(+)$ or disadvantage (-) to ECSEL courses compared with non-ECSEL courses, with the non-ECSEL reference group mean set at the 50th percentile.

${ }^{c}$ Loaded at .40 on two or more factors and, therefore, was excluded because of ambiguity of interpretation. 
Table 3 also reports (at the bottom) the group means on 8 items that the factor analysis suggested contributed to more than one factor and were, thus, interpretively unclear. Because of that lack of factorial clarity, the items and their group means are reported individually. In all cases, the ECSEL group mean is higher than that of the non-ECSEL group, with effect size advantages ranging from 11 to 26 percentile-points.

\section{Multivariate Analyses of Learning Outcomes}

Because students self-selected themselves into the ECSEL and non-ECSEL courses, however, it is possible that the differences in group scale and item means described above may have been due to pre-course differences among the students. Students with certain ability or motivational levels (and other characteristics) may have been more likely to enroll in one kind of course than the other. To explore this possibility, three multiple regression analyses (one each for the design, communications, and group skills scales) were conducted. This analytical procedure permits evaluation of whether (and to what extent) differences in the two groups' reported gains persist at statistically significant levels while controlling for student differences in certain pre-course characteristics. In each of the three regressions, gender, race/ethnicity, parents' education, high school achievement (GPA), academic ability (SAT verbal and math scores), degree aspirations, and class year (lower v. upper division) were controlled.

In each regression, group membership (i.e., taking an ECSEL vs. A non-ECSEL course) was significantly related to reported gains net of other student differences. Thus, the greater gains in their design, communication, and group skills reported by ECSEL students persist even after a number of potentially confounding pre-course differences are taken into account. Indeed, the differences in gains on each scale were influenced substantially more by type of course taken than by any of the pre-course student characteristics. Such results lend credence to a claim that ECSEL is having a positive and apparently substantial educational influence on student learning in a variety of outcome areas identified by ABET and industry as important for the development of future engineers.

Table 4 reports other survey items dealing with reported course-related changes in other outcome areas. In virtually every instance, the ECSEL group mean is higher than that of their non-ECSEL peers, although the differences are statistically significant on only 3 items. ECSEL course students (compared to non-ECSEL course students) expect a higher grade (and grades are positively related to persistence), report developing greater confidence in their ability to become an engineer, and report a higher likelihood that they will become a practicing engineer. 
Table 4. Reported Changes Due to Course

\begin{tabular}{|c|c|c|c|}
\hline \multirow[b]{2}{*}{ Change Attributable to Course in: } & \multicolumn{2}{|c|}{ Means $^{a}$} & \multirow[b]{2}{*}{$\begin{array}{c}\text { Effect }^{\text {Size }} \\
\end{array}$} \\
\hline & $\underset{(n=299-306)}{\text { ECSEL }}$ & $\begin{array}{l}\text { Non-ECSEL } \\
(\mathbf{n}=131-136)\end{array}$ & \\
\hline $\begin{array}{l}\text { Confidence in ability to become an engineer. } \\
\text { Likelihood of becoming a practicing engineer. } \\
\text { Expected grade in this course }(1=\mathrm{D} / \text { below to }\end{array}$ & $\begin{array}{l}3.64 \\
3.76 \\
6.03\end{array}$ & $\begin{array}{l}3.40 \\
3.54 \\
5.44\end{array}$ & $\begin{array}{l}10 \\
9 \\
14\end{array}$ \\
\hline $\begin{array}{l}\text { Motivation to become an engineer. } \\
\text { Sense of responsibility for own learning. } \\
\text { Likelihood of continuing in engineering. } \\
\text { Likelihood of going on to graduate school in } \\
\text { engineering. }\end{array}$ & $\begin{array}{l}3.61 \\
3.91 \\
3.81 \\
3.44\end{array}$ & $\begin{array}{l}3.42 \\
3.93 \\
3.65 \\
3.34\end{array}$ & \\
\hline $\begin{array}{l}\text { Likelihood of pursuing a teaching career in } \\
\text { engineering. }\end{array}$ & 2.93 & 2.87 & \\
\hline
\end{tabular}

${ }^{a}$ Differences in means with an effect size reported are significantly different at $\mathrm{p}<.01$ or smaller.

${ }^{\mathrm{b}}$ Difference in means represented in percentile-point units. Effect size represents the advantage (+) or disadvantage (-) to ECSEL courses compared with non-ECSEL courses, with the non-ECSEL reference group mean set at the 50th percentile.

\section{Conclusions}

The fact that the results reported here are based on pilot-test data from a sample of students and courses not drawn at random from the population of ECSEL and non-ECSEL courses offered on ECSEL's seven campuses limits the generalizability of the conclusions that can be reached. Those constraints are counterbalanced, however, by the psychometric strengths of the items and scales used and by the consistent and substantial magnitudes of the advantages ECSEL students appear to enjoy (when contrasted with their peers in non-ECSEL courses), even after controlling differences in potentially confounding pre-course student characteristics. The advantages are apparent, first, in the greater exposure ECSEL-course students receive to instructional methods, activities, and conditions that other research has shown to be pedagogically effective. But not only are ECSEL courses demonstrably different from non-ECSEL courses, their educational impacts also appear to be different. ECSEL students appear to derive significant learning advantages reflected in the consistently greater gains they report on a variety of learning outcomes, including design skills, communication skills, and interpersonal functioning in groups. In short, ECSEL courses appear (at least in these data) not only to be significantly different from non-ECSEL courses in the kinds of things that go on in class, but they also appear to produce substantially greater learning gains.

\section{Implications}

These results have implications for accreditation, classroom management, curriculum, faculty development, and the recruitment and retention of under-represented groups in the field of Engineering. 
An emphasis on active, collaborative learning through the early and pervasive use of design in the engineering curriculum is a major goal of the ECSEL Coalition and one consistent with the goals of ABET 2000 Criteria. This pedagogical strategy has also been shown to promote effective instruction. Student gains in communication skills, design skills, and group participation skills - all endorsed by ABET_-are likely to occur when the classroom experience itself stresses collaborative learning and learning by design. It stands to reason, then, to expect that accreditation efforts highlighting the centrality of the classroom experience and related student learning outcomes will contribute to enhanced engineering program effectiveness.

Structuring classroom activities that promote gains in communication, design, and group skills are by their very nature complex. Developing assignments that call for design-based learning, coupled with the emphasis on constant feedback, will require specialized ability and knowledge that only training or substantial experience can provide. Strong commitment on the part of a department or the college will be needed to facilitate the constant upgrading of critical teaching skills and techniques.

The effort required in designing curricula that foster learning by design and collaborative learning raises another critical administrative consideration: the role of teaching in promotion, tenure, and salary decisions. An assistant professor or even an associate professor torn between the competing demands for teaching, research, and service will see little benefit in learning-by-design activities and in promoting collaborative learning if these activities are neglected when significant personnel decisions are made. Interviews with both ECSEL and non-ECSEL faculty point to this consideration as a major deterrent to their involvement in teaching design-based courses. If engineering colleges do, indeed, value gains in students' design, problem-solving, group, and communication skills, then the colleges and their host institutions must examine the extent to which their faculty reward criteria, standards, and policies provide adequate incentives to encourage faculty to pursue these instructional goals.

While the nature of the classroom activities are, in themselves, important, the conditions surrounding teaching cannot be neglected. Mounting evidence suggests a negative association between collegiate experiences and women's self-confidence in pursuing "hard" majors (e.g., Drew, 1996). In this context, our findings that women do not believe they are treated the same as males is distressing and runs counter the ECSEL goal of promoting access and persistence for under-represented groups. Faculty development appears to be critical for improving the classroom climate for under-represented groups (e.g., Cabrera \& Nora, 1994; Drew, 1996). Training faculty in classroom management and teaching faculty about the cultures and learning styles of women and under-represented minorities can be expected to ameliorate this problem, at least in part. Equally needed is the implementation of feedback mechanisms that will enable both administrators and faculty to assess the classroom experiences of women and under-represented minorities. While the information is vital, decisive actions on the part of faculty and administrators can, indeed, convey a clear message to women and minorities as to the value the institution places on diversity and equitable treatment. 


\section{References}

Cabrera, A. F., \& Nora, A. (1994). College students' perceptions of prejudice and discrimination and their feelings of alienation. Review of Education, Pedagogy and Cultural Studies, 16, 387-409.

Drew, D. (1996). Aptitude revisited: Rethinking math and science education for America's next century. Baltimore, MD: The Johns Hopkins University Press.

Accreditation Board for Engineering and Technology. (1997). Engineering criteria 200: Criteria for accrediting programs in engineering in the United States. Prism, March 1997, 41-42

Jones, E. A. (1994, July). Goals inventories. University Park, PA: The Pennsylvania State University, Center for the Study of Higher Education, National Center on Postsecondary Teaching, Leaning, and Assessment.

Jones, E. A., with Hoffman, S., Moore, L. M., Ratcliff, G., Tibbetts, S., \& Click, B. A. (1994, December). Essential skills in writing, speech and listening, and critical thinking: Perspectives of faculty ,employers, and policy makers. University Park, PA: The Pennsylvania State University, Center for the Study of Higher Education, National Center on Postsecondary Teaching, Leaning, and Assessment.

Pascarella, E. T., \& Terenzini, P. T. (1991). How college affects students: Findings and insights from twenty years of research. San Francisco: Jossey-Bass. 
PATRICK T. TERENZINI is professor of higher education and senior scientist in the Center for the Study of Higher Education at Pennsylvania State University. Dr. Terenzini co-directs the evaluation of the ECSEL Coalition. His research interests are in learning outcomes assessment and the effects of college on students. He may be contacted by phone at (814) 865-6346 or e-mail <ptt2@ psu.edu>.

ALBERTO F. CABRERA is an associate professor of higher education and senior associate in the Center for the Study of Higher Education at Pennsylvania State University. His research examines student retention (particularly among under-represented students), college outcomes, and financial aid policy.

JOHN M. PARENTE is a first-year doctoral student in Penn State's Graduate Program in Higher Education and a research assistant in the Center for the Study of Higher Education. His interests are in faculty roles and rewards.

STEFANI A. BJORKLUND is a second-year doctoral student in the Graduate Program in Higher Education and a research assistant in the Center for the Study of Higher Education at Penn State. She's interested in public policy affecting higher education. 


\section{CLASSROOM ACTIVITIES AND OUTCOMES SURVEY}

This survey is part of an on-going effort to provide administrators, faculty, and staff of your college/school of engineering with information they can use to improve the quality of engineering education for you and future students. This study is part of a larger project, called ECSEL, involving seven engineering colleges and schools (including yours) from around the country. The questionnaire asks about your family and educational background, your experiences in this course, and your perceptions about how much this course may have shaped your engineering-related skills.

With the support of the National Science Foundation, ECSEL is attempting to (1) integrate design into the engineering curriculum, and (2) increase the number and retention of under-represented groups in the engineering student body. Penn State's Center for the Study of Higher Education is responsible for gathering information on how well these goals are being achieved, and this survey is part of that effort.

Completing the questionnaire will take only about 10 minutes, and your responses will be completely anonymous (do not put your name on the questionnaire). You are, of course, free to decline to participate in this evaluation or to answer any specific question, although we hope you will choose to help us and your engineering program. Completion of the questionnaire will be considered your consent to participate.

If you have any questions, please feel free to contact me by phone (814-865-6346) or email (ptt2@psu.edu) at any time. Thanks for your assistance.

Sincerely,

Patrick T. Terenzini, Director

ECSEL Evaluation Group

Pennsylvania State University 


\section{CLASSROOM ACTIVITIES AND OUTCOMTES SURVEY}

Directions: Please write the requested information in the space provided or circle the number that best reflects your answer to the question. There are no "right" or "wrong" answers to these questions. We appreciate your assistance.

\section{Background Information}

1. University's name:

2. Course No. and Title:

3. Declared/Expected Major:

4. Gender: $0=$ Female $1=$ Male

5. Race/ethnicity with which you most closely identify:

$1=$ Black/African American

$2=$ Hispanic/Latino American

$3=$ Asian $/$ Pacific Islander

$$
\begin{aligned}
& 4=\text { American Indian/Alaskan Native } \\
& 5=\text { White/Caucasian } \\
& 6=\text { Other: }
\end{aligned}
$$

6. Class year: $1=$ freshman $2=$ sophomore $3=$ junior $4=$ senior $5=$ Other

7. What is the highest level of formal education completed by your parents?

\begin{tabular}{|c|c|c|c|}
\hline Grammar school or less & 1 & 1 & College degree \\
\hline $\begin{array}{l}5 \\
6\end{array}$ Some high school & 2 & 2 & Some graduate school \\
\hline High school graduate & 3 & 3 & Master's degree \\
\hline Some college/associate's degree & 4 & 4 & Doctorate/Professional degree 8 \\
\hline
\end{tabular}

\section{Mother Father}

Mother Father

8. Highest degree expected in your lifetime: $1=$ Bachelor's $2=$ Master's $3=$ Doctorate

9. Approximately how many hours per week are you employed:
a) On-campus: hrs./week
b) Off-campus: hrs./week

10. SAT Scores: Verbal: Math:

11. GPA: In high school: In engineering: Currently, overall:

12. No. of courses successfully completed to-date in: engineering ; science/math

13. Did you: $1=$ enter college at this university, or $2=$ transfer from another college/univ. 14. Are you now living in:

$1=$ a dormitory/college housing

$2=\mathrm{a}$ fraternity/sorority house
$3=$ a private apartment/room off-campus

$4=$ at home with a parent, spouse, or relative

$4 / 29 / 98$ 


\section{This section asks about the characteristics of this course and the kinds of activities that go on in it. Using the scale below, please circle the number that best reflects how often you have experienced the following in this course:}

$\mathbf{1}=$ Never $\quad \mathbf{2}=$ Occasionally $\mathbf{3}=$ Often $\quad \mathbf{4}=$ Very Often/Almost Always $\mathbf{n} / \mathbf{a}=$ Not applicable

\section{In this course:}

a) Assignments and class activities are clearly explained. $\quad \begin{array}{lllll} & 2 & 3 & 4\end{array}$ $\mathrm{n} / \mathrm{a}$

b) Assignments, presentations, and learning activities are clearly $\quad \begin{array}{lllllll}1 & 2 & 3 & 4 & \text { n/a }\end{array}$ related to one another.

c) I work cooperatively with other students on course assignments. $\quad \begin{array}{llllll}1 & 2 & 3 & 4 & \text { n/a }\end{array}$

d) Students teach, and learn from, each other. $\quad 1 \quad 2 \quad 3 \quad 4 \quad 4$ $\mathrm{n} / \mathrm{a}$

e) There are opportunities to work in groups. $\quad \begin{array}{llllll}1 & 2 & 3 & 4 & \mathrm{n} / \mathrm{a}\end{array}$

f) I'm encouraged to show how a particular course concept can be $\quad \begin{array}{lllllll}1 & 2 & 3 & 4 & \text { n/a }\end{array}$ applied to an actual problem or situation.

g) I have opportunities to practice the skills I'm learning in the course. $\begin{array}{llllll}1 & 2 & 3 & 4 & \mathrm{n} / \mathrm{a}\end{array}$

h) I discuss ideas with my classmates (either individuals or in a group). $\begin{array}{lllllll}1 & 2 & 3 & 4 & \mathrm{n} / \mathrm{a}\end{array}$

I) I get feedback on my work or ideas from my classmates $\quad \begin{array}{llllll}1 & 2 & 3 & 4 & \text { n/a. }\end{array}$

j) We do things that require students to be active participants in $\quad \begin{array}{llllll}1 & 2 & 3 & 4 & \mathrm{n} / \mathrm{a}\end{array}$ the teaching and learning process.

k) The instructor makes clear what is expected of students $\quad \begin{array}{llllll}1 & 2 & 3 & 4 & \text { n/a }\end{array}$ in the way of activities and effort.

1) The instructor gives me frequent feedback on my work. $\quad \begin{array}{llllll}1 & 2 & 3 & 4 & \mathrm{n} / \mathrm{a}\end{array}$

m) The instructor gives me detailed feedback on my work. $\quad \begin{array}{lllllll}1 & 2 & 3 & 4 & \text { n/a }\end{array}$

n) I'm encouraged to challenge the instructor's or other students' ideas. $\begin{array}{llllll}1 & 2 & 3 & 4 & \text { n/a }\end{array}$

o) The instructor guides students' learning activities rather than $\quad \begin{array}{lllllll}1 & 2 & 3 & 4 & \text { n/a }\end{array}$ lecturing or demonstrating the course material.

p) The instructor encourages students to listen, to evaluate, and $\quad \begin{array}{llllll}1 & 2 & 3 & 4 & \mathrm{n} / \mathrm{a}\end{array}$ to learn from the ideas of other students.

q) The instructor treats women students in the same way as male students.1 $2 \begin{array}{lllll}2 & 3 & 4 & \text { n/a }\end{array}$

r) The instructor treats minority students in the same way as white students $\begin{array}{llll}1 & 2 & 3 & 4\end{array}$ $\mathrm{n} / \mathrm{a}$

s) Some male students treat women students differently from $\quad \begin{array}{llll}\text { S } & 2 & 3 & 4\end{array}$ $\mathrm{n} / \mathrm{a}$ other male students. 
t) Some white students treat minority students differently from $\quad \begin{array}{llllll}1 & 2 & 3 & 4 & \text { n/a }\end{array}$ other white students.

u) When working in groups, some male students treat women students $\quad \begin{array}{lllll}1 & 2 & 3 & 4\end{array}$ $\mathrm{n} / \mathrm{a}$ differently from other male students.

$\mathbf{1}=$ Never $\quad \mathbf{2}=$ Occasionally $\mathbf{3}=$ Often $\mathbf{4}=$ Very Often/Almost Always $\mathbf{n} / \mathbf{a}=$ Not applicable

\section{In this course:}

v) When working in groups, some white students treat minority students $\begin{array}{llll}1 & 2 & 3 & 4\end{array}$ $\mathrm{n} / \mathrm{a}$ differently from other male students.

w) The instructor emphasizes the design process and activities.

$\mathrm{x})$ I interact with the instructor as part of this course. $\begin{array}{lllll}1 & 2 & 3 & 4 & \mathrm{n} / \mathrm{a}\end{array}$

y) I interact with this instructor outside of class. $\begin{array}{lllll}1 & 2 & 3 & 4 & \mathrm{n} / \mathrm{a}\end{array}$

z) I interact with other students in this course outside of class. $\begin{array}{lllll}1 & 2 & 3 & 4 & \mathrm{n} / \mathrm{a}\end{array}$ $\mathrm{n} / \mathrm{a}$

III. This section asks about the progress you believe you've made in a variety of areas as a result of taking this course. Using the scale below, please circle the number that best reflects how much progress you believe you have made in each area.

$$
1=\text { None } \quad 2=\text { Slight } \quad 3=\text { Moderate } \quad 4=\text { A Great Deal }
$$

Progress made, because of this course, in your:

a) Understanding of what engineers "do" in industry or as faculty members. $\quad \begin{array}{rrrr}1 & 2 & 3 & 4\end{array}$

b) Understanding of engineering as a field that often involves non-technical $\quad \begin{array}{llll}1 & 2 & 3 & 4\end{array}$ considerations (e.g., economic, political, ethical, and/or social issues).

c) Knowledge and understanding of the language of design in engineering $\quad \begin{array}{llll}1 & 2 & 3 & 4\end{array}$

d) Knowledge and understanding of the process of design in engineering. $\quad 1 \quad 2 \quad 3$ 4

Your Ability to . . .

e) "Do" design. $\quad \begin{array}{llll} & 2 & 3 & 4\end{array}$

f) Solve an unstructured problem (that is, one for which no single "right" $\quad \begin{array}{llll}1 & 2 & 3 & 4\end{array}$ answer exists).

g) Identify the knowledge, resources, and people needed to solve $\quad 1 \quad 2 \quad 3$ 4 an unstructured problem 
h) Evaluate arguments and evidence so that the strengths and weaknesses $\quad \begin{array}{lll}2 & 3\end{array}$ 4 competing alternatives can be judged.

i) Apply an abstract concept or idea to a real problem or situation. $\quad \begin{array}{llll}2 & 3 & 4\end{array}$

j) Divide unstructured problems into manageable components. $\quad \begin{array}{llll}2 & 3 & 4\end{array}$

k) Clearly describe a problem orally. $\quad 1 \quad 2 \quad 3 \quad 4$

1) Clearly describe a problem in writing. $\quad 1 \quad 2 \quad 3 \quad 4$

m) Develop several methods that might be used to solve an unstructured $\quad \begin{array}{llll}1 & 2 & 3 & 4\end{array}$ problem. 


$$
\mathbf{1}=\text { None } \quad \mathbf{2}=\text { Slight } \mathbf{3}=\text { Moderate } \mathbf{4}=\text { A Great Deal }
$$

Progress made, because of this course, in your ability to:

n) Identify the tasks needed to solve an unstructured problem.

o) Visualize what the product of a project would look like.

p) Weight the pro's and con's of possible solutions to a problem.

$\begin{array}{llll}1 & 2 & 3 & 4\end{array}$

q) Figure out what changes are needed in prototypes so that the final engineering project meets design specifications.

r) Develop ways to resolve conflict and reach agreement in a group.

$\begin{array}{llll}1 & 2 & 3 & 4\end{array}$

s) Pay attention to the feelings of all group members.

$\begin{array}{llll}1 & 2 & 3 & 4\end{array}$

t) Listen to the ideas of others with an open mind.

u) Work on collaborative projects as a member of a team.

v) Organize information into categories, distinctions, or frameworks that will aid comprehension.

w) Ask probing questions that clarify facts, concepts, or relationships.

x) After evaluating the alternatives generated, to develop a new alternative that combines the best qualities and avoids the disadvantages of the previous alternatives.

IV. Using the scale below, please indicate the extent (if any) to which you may have changed in any of the areas listed as a result of taking this course:

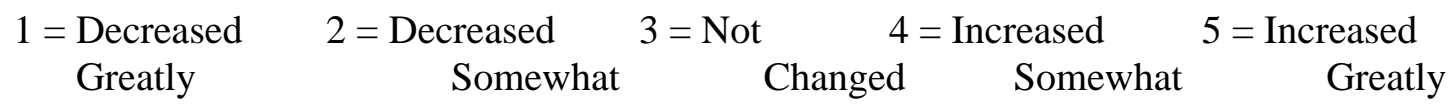

\section{As a result of taking this course:}

a) Your confidence that majoring in engineering was the right choice for you. .12 $3 \quad 4 \quad 4 \quad 5$

b) Your confidence in your ability to become an engineer has . . . $\quad 1 \quad 1 \quad 2 \quad 3445$

c) Your motivation to become an engineer has . . . $\quad 1 \quad 2 \quad 3 \quad 4 \quad 5$

d) Your sense of being responsible for your own learning has . . . $\quad 1 \quad 1 \quad 2 \quad 3 \quad 4 \quad 5$

e) The likelihood you will continue in your engineering program has . . . $\quad \begin{array}{llll}2 & 2 & 3 & 4\end{array}$ 5

f) The likelihood you will go on to graduate school in engineering has . . . $\quad \begin{array}{llll} & 1 & 2 & 3\end{array}$ 
g) The likelihood you will pursue a teaching career in engineering has . . . $1 \begin{array}{lllll}1 & 2 & 3 & 4 & 5\end{array}$

h) The likelihood you will become a practicing engineer has . . . $\quad 1 \quad 2 \quad 34$ 5

i) What grade do you expect to receive in this course?

$1=\mathrm{A}-$ /above $\quad 2=\mathrm{B}+\quad 3=\mathrm{B} \quad 4=\mathrm{B}-\quad 5=\mathrm{C}+\quad 6=\mathrm{C} \quad 7=\mathrm{C}-\quad 8=\mathrm{D} / \mathrm{below}$

j) On average, how many hours per week do you spend studying for this course? hrs./wk.

Thanks very much for your help!

Please return completed questionnaires to whomever distributed them to the class. 